原著

\title{
鉛投与ラットの硬組織中 $\mathrm{Pb}, \mathrm{Ca}, \mathrm{P}$ 含有量 におよばすたん白栄養の影響
}

\author{
丹羽 源 男*
}

掫要 : 生体に有害な鉛の硬組織への取り込みを栄䅈状態の関連において調へた。すなわち，young，

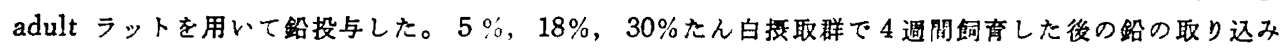
は $5 \%$ たん白摄取群が他群にくらべ大きく，さらに adult 群よりも young 群が鉛取り込み量が大きか

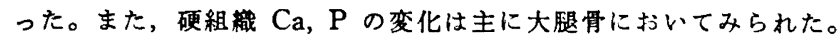

\section{I. 緒 言}

鉛は生体污染物梊として，貝血や神経組織など生体に 悪影響を及ほし1，また硬組織にも沈着し，種々の阻害 を起すことはよく知られている2)。一方, 鉛は生体自身 の年龄や栄養状態によって，そのレスポンスも異なるこ とは十分，想像される。生体の栄養状態を把握する上 で，たん白栄美は成長，発育に特に重要であることは当 然であるが，鉛投与の硬組織中金属含有是とたん白栄養 の関連性については，ほとんど評価できる報告を見出せ ない。

著者は，実験的に食餌中に含まれた鉛が生体のたん白 捸取レベルによりどの程度取り込まれるかについて，ま た，鉛によって硬組織中 $\mathrm{Ca}, \mathrm{P}$ がどのように変化する かについて研究を行い, 興味ある結果を得たので報告す る。

\section{II. 実験方法}

\section{1. 実験動物}

donryu 系雄ラット 3 週軨 (young 群) 30匹，5 カ月 紫 (adult 群) 30匹の計60匹を用い，各群の体重が均一 になるように分けた。

\section{2. 飼育条件}

すべてのラットを18\%カゼイン食にて 1 週間飼育調整 し，その後，直ちに各群 5 匹になるよ5に $5 \%$, 18\%, 30\%カゼイン食レベルに分別し(表 1), さらにコントロ
Table 1 Composition of the diet (q6)

\begin{tabular}{l|c|c|c}
\hline & $5 \%$ & $18 \%$ & $30 \%$ \\
\hline Casein & 5 & 18 & 30 \\
Corn starch & 80 & 67 & 55 \\
Soy bean Oil & 10 & 10 & 10 \\
Salt mixture a) $^{\text {a) }}$ & 5 & 5 & 5 \\
Vitamin mixture $^{\text {b) }}$ & $*$ & $*$ & $*$
\end{tabular}

a) Composition ( $\mathrm{mg} / 100 \mathrm{~g}$ diet) : $\mathrm{NaCl}, 1253$; $\mathrm{KI}, 0.025 ; \mathrm{KH}_{2} \mathrm{PO}_{4}, 1715.5 ; \mathrm{CaHPO}_{4} \cdot 2 \mathrm{H}_{2} \mathrm{O}$, 21.5 ; $\mathrm{CaCO}_{3}, 1464.5 ; \mathrm{MgSO}_{4} \cdot 7 \mathrm{H}_{2} \mathrm{O}, 499$; $\mathrm{FeC}_{6} \mathrm{H}_{5} \mathrm{O}_{7} \cdot 6 \mathrm{H}_{2} \mathrm{O}, 31.15 ; \mathrm{CuSO}_{4} \cdot 5 \mathrm{H}_{2} \mathrm{O}, 7.80$; $\mathrm{ZnCl}_{2}, 1.00 ; \mathrm{MnSO}_{4} \cdot \mathrm{H}_{2} \mathrm{O}, 6.05 ;\left(\mathrm{NH}_{4}\right)_{6} \mathrm{Mo}_{7} \mathrm{O}_{2}$. $4 \mathrm{H}_{2} \mathrm{O}, 0.125$.

b) Composition ( $\mathrm{mg} / 100 \mathrm{~g}$ diet) : thiamin, 0.5 ; riboflavin, 0.8 ; pyridoxine, 0.5 ; nicotinic acid, 4.0 ; p-Ca-Pantothenate, 4.0 ; folic acid, 0.4 ; cyanocobalamin, 0.003 ; biotin, 0.04 ; myoinositol, 10 ; $p$-amino-benzoic acid 10 ; choline, 200 ; retinol, 1000 ; ergocalciferol, $100 \mathrm{IU}$; $\alpha$-tocopherol, 4 ; menaquinone, 0.5 .

一ル群，鉛群に分けた。鉛群には， $1 \mathrm{~m} \mathrm{~mol} / \mathrm{kg}$ 体重に なるよ5に酢酸鉛をカゼイン食中に混ぜ，1日につき young 群, adult 群にそれぞれ $12 \mathrm{~g}, 15 \mathrm{~g}$ のカゼイン食 を与えた。飼育室温は $24 \pm 4^{\circ} \mathrm{C}$ であった。

3. 测定項目

ラットが鉛中毒症状を呈しているかを確認するため, 各週毎に体重を測定し, 実験 4 週後にエーテル麻酔下で

* 日本齿科大学衛生学教室（主任: 锂沼萂吾教授)

* Department of Hygiene, Nippon Dental University, Tokyo (Director: Prof. Bogo KOINUMA) 昭和54年10月15日受付 
Table 2 Body weight change (g)

\begin{tabular}{lccc|ccc}
\hline \multicolumn{3}{c|}{ Young } & \multicolumn{3}{c}{ Adult } \\
\hline Casein (96) & 5 & 18 & 30 & 5 & 18 & 30 \\
Control & $116 \pm 6$ & $183 \pm 7$ & $194 \pm 10$ & $347 \pm 27$ & $375 \pm 16$ & $377 \pm 16$ \\
$\mathrm{~Pb}$ & $80 \pm 1^{* *}$ & $177 \pm 8$ & $172 \pm 6^{* *}$ & $350 \pm 19$ & $366 \pm 17$ & $369 \pm 14$
\end{tabular}

Table values are mean + S. D. for 5 rats per each group.

** Values are significantly different from adult group at $\mathrm{P}<0.01$.

腋下動静脈血を操取し血中鉛を测定した。

各種たん白撜取レベルでの硬組織中鉛含有量を調べる ため, 屠殺後に大腿骨, 切歯， 曰歯を摘出，分離し， $60^{\circ} \mathrm{C}$ にて48時間，乾燥し，科量し，それぞれ硝酸一過 塩素酸にて湿式灰化し，灰化液の鉛含有㷦をフレームレ 又原子吸光装置 (Varian Tectron 社, 1100型) にて测 定した ${ }^{8,4)}$ 。

各硬組織中の主成分である $\mathrm{Ca}, \mathrm{P}$ 量を測定するため に灰化液を用いて $\mathrm{Ca}$ は原子吸光法, PはF Fiske-Sabbarow 法による比色定量法引)にて定量を行った。

\section{III. 結 果}

（I）各たん白摇取レベルのラット成長への鉛の影響 表 2 に young, adult 群の 4 週経過後の体重変化を示 した。即ち, young 群では鉛群がコントロール群にく らべ，体重が低く，特に $5 \%$ \%白群の低下は著明であ った。adult 群では鉛群, コントロール群に差はほとん ど認められなかった。血液へマトクリット值は表 3 に示 した通り，young 群では鉛群がコントロール群より低
Table 3 Hematocrit (\%)

\begin{tabular}{lrll}
\hline & Casein (\%) & Young & Adult \\
\hline \multirow{3}{*}{ Control } & 5 & $46.2 \pm 2.15$ & $49.2 \pm 1.92$ \\
& 18 & $48.8 \pm 2.49$ & $50.2 \pm 1.79$ \\
& 30 & $49.0 \pm 2.92$ & $50.2 \pm 2.68$ \\
\hline \multirow{3}{*}{$\mathrm{Pb}$} & 5 & $39.6 \pm 2.97^{*}$ & $45.0 \pm 1.41^{*}$ \\
& 18 & $44.6 \pm 2.51^{*}$ & $47.8 \pm 0.84^{*}$ \\
& 30 & $48.6 \pm 1.67^{*}$ & $48.4 \pm 0.89$
\end{tabular}

* Significantly different from control group at $\mathrm{P}<0.05$.

い傾向にあり，体重减少と同様，5\%たん白群で最低値 を示し, adult 群も同様な傾向であったが, young 群に くらべて高い差を認めなかった。

（II）各たん白摄取レベルのラット体内への鉛の取り 込み

表 4 に血中鉛量，硬組織中鉛含有量を示した。即ち， young 群では $5 \%$ たん白群で平均 $28.9 \mathrm{ppm}$ と非常に高 浪度であり，他のたん白群では顕著な値は見出せなかっ

Table 4 Amount of Lead in blood and hard tissues

\begin{tabular}{|c|c|c|c|c|c|c|}
\hline & & Casein (\%) & Blood $(\mu \mathrm{g} / \mathrm{ml})$ & Femur $(\mu \mathrm{g} / \mathrm{g})$ & Incisor $(\mu \mathrm{g} / \mathrm{g})$ & Molar $(\mu \mathrm{g} / \mathrm{g})$ \\
\hline \multirow{6}{*}{ Young } & \multirow{3}{*}{ Control } & 5 & $0.46 \pm 0.02$ & $2.41 \pm \quad 0.04$ & $1.46 \pm 0.26$ & $1.38 \pm \quad 0.31$ \\
\hline & & 18 & $0.52 \pm 0.05$ & $1.56 \pm 0.07$ & $1.23 \pm 0.41$ & $1.42 \pm \quad 0.45$ \\
\hline & & 30 & $0.24 \pm 0.03$ & $1.72 \pm \quad 0.06$ & $1.41 \pm 0.32$ & $2.04 \pm \quad 0.82$ \\
\hline & \multirow{3}{*}{$\mathrm{Pb}$} & 5 & $28.91 \pm 0.42^{* *}$ & $1505.67 \pm 247.31^{* *}$ & $444.23 \pm 35.45^{* *}$ & $539.44 \pm 53.91^{* *}$ \\
\hline & & 18 & $1.48 \pm 0.15^{* *}$ & $1199.15 \pm 328.13^{* *}$ & $307.17 \pm 44.70^{* *}$ & $497.68 \pm 85.42^{* *}$ \\
\hline & & 30 & $1.67 \pm 0.23^{* *}$ & $1150.41 \pm 290.69 * *$ & $218.63 \pm 35.19^{* *}$ & $492.18 \pm 91.66^{* *}$ \\
\hline \multirow{6}{*}{ Adult } & \multirow{3}{*}{ Control } & 5 & $0.29 \pm 0.01$ & $4.52 \pm \quad 0.60$ & $2.45 \pm 0.72$ & $3.45 \pm \quad 0.57$ \\
\hline & & 18 & $0.25 \pm 0.03$ & $4.60 \pm \quad 0.82$ & $1.83 \pm 0.22$ & $2.84 \pm \quad 0.72$ \\
\hline & & 30 & $0.15 \pm 0.01$ & $4.32 \pm \quad 0.94$ & $1.53 \pm 0.42$ & $4.56 \pm \quad 0.48$ \\
\hline & \multirow{3}{*}{$\mathrm{Pb}$} & 5 & $1.06 \pm 0.21 * *$ & $197.43 \pm 26.77^{* *}$ & $164.98 \pm 24.11^{* *}$ & $305.07 \pm 31.48^{* *}$ \\
\hline & & 18 & $0.49 \pm 0.14^{* *}$ & $82.23 \pm 14.29 * *$ & $141.91 \pm 27.44^{* *}$ & $304.49 \pm 100.0^{* *}$ \\
\hline & & 30 & $0.87 \pm 0.08 * *$ & $66.71 \pm 15.64^{* *}$ & $145.53 \pm 39.02^{* *}$ & $251.83 \pm 76.18^{* *}$ \\
\hline
\end{tabular}

** Significantly different from control group at $\mathrm{P}<0.01$. 


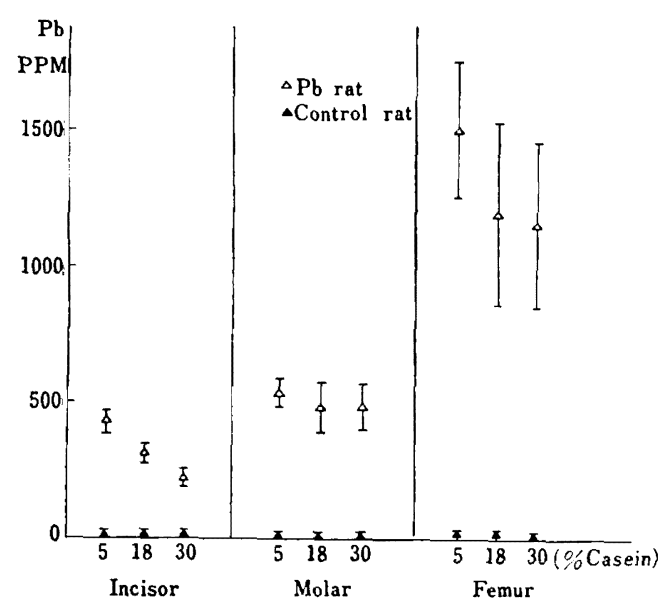

Fig. $1 \mathrm{~Pb}$ Concentration in young rat hard tissues.

たが, 全ての群で鉛群がコントロール群に比して鉛含有 量が大きかった。adult 群でも5\%たん白群が他群に比 して高湛度であったが, young 群ほどの差ではなかっ た。

硬組織として切歯，臼歯，大腿骨を選ひ，図 1，2に 示した。即ち, 切歯では young, adult 群とも5\%たん 白群が高い含有量を示したが，young 群は adult 群よ り高かった。一方，臼歯はたん白掑取レベルによる鉛含 有量の差は切歯ほどでなく, young 群は, adult 群のほ ほ 2 倍の含有量であった。大服骨においては young, adult 群とも $5 \%$ たん白群で他のレベルより非常に高い 含有量を示した。

（III）硬組織中 $\mathrm{Ca}, \mathrm{P}$ 人の鉛の影響 young, adult 両群の各種たん白鼬取レベルでの $\mathrm{Ca}$, $\mathrm{P}$ 量, さらに $\mathrm{Ca} / \mathrm{P}$ 比を表 5,6 に示した。切歯, 田歯 両群とも著明な変化は $\mathrm{Ca}$ の場合, 臼歯の young 群30 \%たん白群の差のみであった。一方，大祣骨の場合は， 鉛の影響が大きく, young 群において Ca, P が全ての 群でコントロール群より高い含有量を示し, adult 群で も主に低タンパク食で高い含有量を示した。

$\mathrm{Ca} / \mathrm{P}$ 比の変化は, 各組織とも young 群では鉛によ

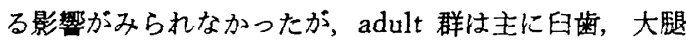
骨で $\mathrm{Ca} / \mathrm{P}$ 比に差があった。

\section{IV. 考 察}

我々が一般に微量元素を取りあつから場合は，もし， それが人体に有益である場合は栄養にとって微量で非常

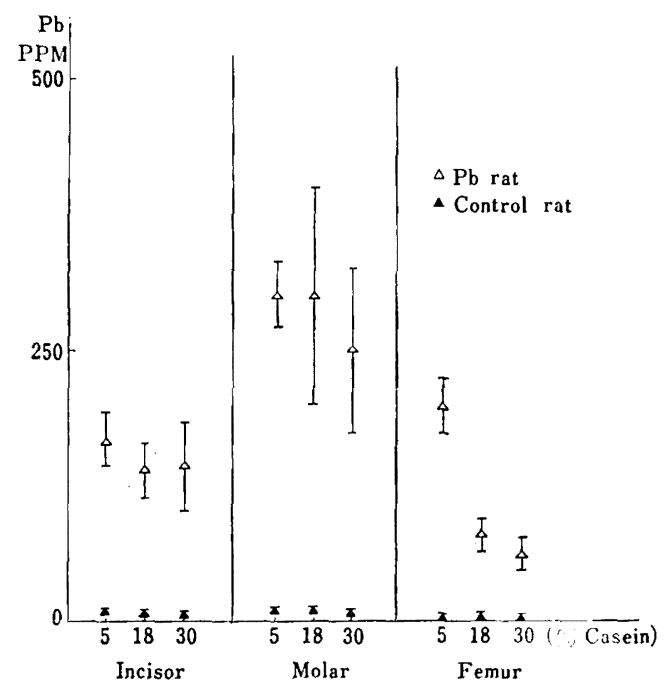

Fig. 2 Pd Concentration in adult rat hard tissues.

に有効であるといえるが，鉛やカドミウムなど有害元秦 は衛生学上からみても, 綮重な取扱い注意の临起が必要 である。食品中に混入する有害微量元素は，生体内に入 る前の污染状態のみならず，生体中に入った場合に生体 自身のもつ防御作用も十分考える必要がある。その意味 から鉛中毒と栄養状態の関連を把握しようとして本実験 を行ったわけであるが，鉛はその蓄䆅状況により毒性を 発揮することから蓄積の把握は毒性を示す絶対条件とい える日)。

本実験の場合, 侵入経路モデルとして経口を考え, 食 䣽中に鉛を混入させたが，食物摄取の場合は $5 \%$ から10 \%のみが腸管より吸収され，経気道掑取による30〜 50\% の鉛吸収の結果にくらべて少量といわれる7。生体内に 入った鉛は必ず血流に入ることから血中鉛量を測定した が, young, adult 群ともに鉛群 $5 \%$ たん白群がコント ロール群にくらべ高いことについては早川らきは鉛の腸 管吸収実験を行ってカゼイン量の少ないほど吸収量が大 きく，跺がタンパクと不溶性の complex をつくり，腸 管から吸収されにくくなるのではないかと推論してい る。早川らの実験では, 幼若ラットを使い, 硝酸鉛溶液 を自由搨取させ，カゼイン食 $9 \%$ 群が $18 \%$ 群より約 5 倍 の血中鉛量を認めている。

鉛の硬組織への取り込みは大腿骨の場合, young 群, adult 群ともに $5 \%$ たん白群が $18 ， 30 \%$ たん白群より高 い値を示したが，血中鉛量と対応がとれていることは密 接な関連性を示している。また, 歯牙については, 切歯 が young, adult 群とも5\%たん白群が大腿骨と同様な 
Table 5 Amount of $\mathrm{Ca}$ and $\mathrm{P}$ in hard tissues (\%)

\begin{tabular}{|c|c|c|c|c|c|c|c|c|}
\hline \multirow{8}{*}{ Young } & & \multirow{3}{*}{$\frac{\text { Casein (क6) }}{5}$} & \multicolumn{2}{|c|}{ Incisor } & \multicolumn{2}{|c|}{ Molar } & \multicolumn{2}{|c|}{ Femur } \\
\hline & \multirow{4}{*}{ Control } & & $\mathrm{Ca}$ & P & $\mathrm{Ca}$ & $P$ & $\mathrm{Ca}$ & $\mathrm{P}$ \\
\hline & & & $17.0 \pm 1.7$ & $14.7 \pm 1.7$ & $22.4 \pm 1.1$ & $18.6 \pm 2.4$ & $16.6 \pm 1.0$ & $10.9 \pm 1.9$ \\
\hline & & 18 & $17.8 \pm 0.7$ & $15.4 \pm 1.9$ & $22.0 \pm 1.5$ & $15.7 \pm 2.2$ & $17.0 \pm 1.5$ & $11.3 \pm 0.8$ \\
\hline & & 30 & $17.2 \pm 0.7$ & $16.1 \pm 1.8$ & $22.9 \pm 2.3$ & $15.2 \pm 0.2$ & $17.5 \pm 1.0$ & $7.8 \pm 0.3$ \\
\hline & \multirow{3}{*}{$\mathrm{Pb}$} & 5 & $18.6 \pm 1.0$ & $15.7 \pm 1.5$ & $23.0 \pm 2.2$ & $17.3 \pm 1.7$ & $27.3 \pm 2.8^{* *}$ & $16.3 \pm 0.3^{* *}$ \\
\hline & & 18 & $19.3 \pm 1.2$ & $16.3 \pm 1.2$ & $22.9 \pm 0.9$ & $17.3 \pm 1.3$ & $25.8 \pm 1.4^{* *}$ & $16.4 \pm 1.9^{* *}$ \\
\hline & & 30 & $18.0 \pm 1.1$ & $14.9 \pm 0.6$ & $21.4 \pm 2.1$ & $16.6 \pm 0.7^{* *}$ & $24.6 \pm 2.0 * *$ & $12.5 \pm 1.0^{* *}$ \\
\hline \multirow{6}{*}{ Adult } & \multirow{3}{*}{ Control } & 5 & $14.0 \pm 1.9$ & $13.4 \pm 1.8$ & $24.6 \pm 1.7$ & $15.1 \pm 1.4$ & $18.2 \pm 1.1$ & $9.8 \pm 0.3$ \\
\hline & & 18 & $15.6 \pm 0.4$ & $15.1 \pm 1.2$ & $21.1 \pm 0.6$ & $14.6 \pm 1.4$ & $19.2 \pm 0.6$ & $11.4 \pm 0.7$ \\
\hline & & 30 & $15.7 \pm 0.7$ & $15.2 \pm 0.7$ & $22.6 \pm 1.1$ & $15.0 \pm 1.4$ & $18.2 \pm 1.8$ & $10.8 \pm 1.0$ \\
\hline & \multirow{3}{*}{$\mathrm{Pb}$} & 5 & $17.4 \pm 1.2^{*}$ & $14.9 \pm 1.4$ & $21.3 \pm 2.0^{*}$ & $16.1 \pm 1.3$ & $23.3 \pm 0.5^{* *}$ & $12.4 \pm 0.3^{* *}$ \\
\hline & & 18 & $16.6 \pm 0.9$ & $14.6 \pm 0.7$ & $21.0 \pm 2.0$ & $16.6 \pm 0.6^{*}$ & $24.1 \pm 2.1^{* *}$ & $12.1 \pm 0.6$ \\
\hline & & 30 & $17.4 \pm 1.0^{*}$ & $15.0 \pm 0.9$ & $20.0 \pm 1.3^{*}$ & $16.1 \pm 0.9$ & $21.8 \pm 3.6$ & $11.7 \pm 2.3$ \\
\hline
\end{tabular}

* Significantly different from control group at $\mathrm{P}<0.05$.

** Significantly different from control group at $\mathrm{P}<0.01$.

Table $6 \mathrm{Ca} / \mathrm{p}$ ratios in hard tissues

\begin{tabular}{|c|c|c|c|c|c|}
\hline \multirow{7}{*}{ Young } & \multirow{4}{*}{ Control } & Casein (\%) & Incisor & Molar & Femur \\
\hline & & 5 & $1.16 \pm 0.07$ & $1.22 \pm 0.14$ & $1.53 \pm 0.16$ \\
\hline & & 18 & $1.19 \pm 0.13$ & $1.49 \pm 0.19$ & $1.52 \pm 0.17$ \\
\hline & & 30 & $1.07 \pm 0.13$ & $1.51 \pm 0.15$ & $2.30 \pm 0.43$ \\
\hline & \multirow{3}{*}{$\mathrm{Pb}$} & 5 & $1.19 \pm 0.09$ & $1.33 \pm 0.05$ & $1.68 \pm 0.16$ \\
\hline & & 18 & $1.19 \pm 0.06$ & $1.36 \pm 0.09$ & $1.58 \pm 0.13$ \\
\hline & & 30 & $1.19 \pm 0.07$ & $1.33 \pm 0.14$ & $1.96 \pm 0.09$ \\
\hline \multirow{6}{*}{ Adult } & \multirow{3}{*}{ Control } & 5 & $1.05 \pm 0.10$ & $1.13 \pm 0.10$ & $1.85 \pm 0.11$ \\
\hline & & 18 & $1.04 \pm 0.09$ & $1.44 \pm 0.17$ & $1.69 \pm 0.14$ \\
\hline & & 30 & $1.03 \pm 0.02$ & $1.51 \pm 0.14$ & $1.69 \pm 0.07$ \\
\hline & \multirow{3}{*}{$\mathrm{Pb}$} & 5 & $1.17 \pm 0.07$ & $1.32 \pm 0.09 *$ & $1.85 \pm 0.05$ \\
\hline & & 18 & $1.14 \pm 0.07$ & $1.26 \pm 0.19$ & $1.99 \pm 0.16^{*}$ \\
\hline & & 30 & $1.16 \pm 0.05^{* *}$ & $1.29 \pm 0.07^{*}$ & $2.13 \pm 0.14^{* *}$ \\
\hline
\end{tabular}

* Significantly different from control group at $\mathrm{P}<0.05$.

** Significantly different from control group at $\mathrm{P}<0.01$.

高い値を示しているのに対し，臼歯では，カゼイン群間 に含有量の差がないことは, 切歯, 臼歯のレスポンス, 発生形態的相違に起因すると考えられる。

歯と鉛の関連性については, 主に歯を公害污染指標と 考え，歯の含有量を測定した報告がみられる9,10,11,12,18)。 その中で Strehlow'浮歯が鉛の爆露指標として適し ていると述へ，鉛中毒の乳歯は対照群よりも高い鉛含有 量を示したと報告している。さらに，William ${ }^{18)}$ は鉛に よる空気污染のない地域でも歯牙中鉛の含有量が高い值
を出す地域が認められ，必ずしも空気污染だけが鉛含有 量の決定因子でないと述へている。実験的鉛投与におけ る歯と鉛の関係については堀内ら ${ }^{14}$ が各種鉛化合物を犬 に投与した場合, 酢酸鉛と塩化鉛が他の化合物に比して 多く歯に取り込まれ，また各腧器間の比較では軟組織に 比べて歯牙，大腿骨のような硬組織に多く取り込まれる ことを報告している。さらに西條ら ${ }^{(5)}$ (放射性鉛を犬に 投与して，経日的な挙的をみると，齿，大腿骨とも蓄程 的傾向をはっきり認めたと述へている。また，加龄と歯 


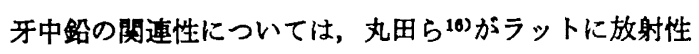
硝酸鉛を投与した実銩で，歯も含めた硬組織一の鉛の取 り込みは幼若ラットほど大きいと報告しており，本実験 の各カゼイン食レベルの值と近似している。ラットの藏 と栄㟴についてはいくらかの報告がみられるが，その中

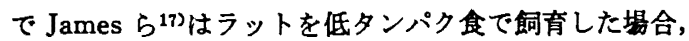
第三曰歯の萠出荤延，咬頭の欠如，咬合面の平滑化が出 現すると述べ，Holloway ら ${ }^{18}$ は低タンパク食飼育ラッ トの歯の幅の堿少を報告している。さらに Menaker ら ${ }^{19)}$ は低栄荃ラットの歯牙萠出パターンが対照群にくら べて大きな差を生じたと述べている。しかし，萠出パタ ーンは離乳期にはすでに萠出完了しており，十分な観察 が出来なかったけれども，著明な症状を示さなかった。

各硬組織の $\mathrm{Ca}, \mathrm{P}$ は大誦骨で young 群が增加して いるが，これは歯にくらべて骨の $\mathrm{C} a, \mathrm{P}$ の代謝が盛ん であるといえるけれども，これを $\mathrm{Ca} / \mathrm{P}$ 比として現わす と young 群では, control 群と差が恝められない。こ れらのことから生体調節が効果的に行われていると示唆 されるが, adult 群では，ほほ Ca 含有量が高くなるた め $\mathrm{Ca} / \mathrm{P}$ 比も高くなり, 差が慧められる。さらに, 本実 験ではいずれのタンパク食レベルとも Harper の塩混合 を用いているので食餌中の他の成分中 $\mathrm{Ca}$ による誤差を 考えても食餌中 $\mathrm{Ca} P$ 比の差は変えられないことから 鉛による硬組織成分の $\mathrm{Ca} / \mathrm{P}$ 比の影響はかなり强いと 推測出来る。

本実験は歯牙をエナメル梊，象牙質に分けなかった が，これは実験の主体が腸管からの鉿吸収，血流を介し ての鉛の取り込みであり，さらに対照群を実験群と等匹 にしていること，またラットの歯牙のサンプルが小さい ことによる分離における誤差を考虑にいれて，歯単位で 測定したものであるが，エナメル啠，象牙質の鉛取り込 み量の差も興味ある問題であり，今後，検討したいと考 えている。

いずれにしても，本実験結果より，栄養タンパクレベ ルと加龄は，硬組織鉛含有量に大きな影整を及ぼし，今 後の鉛污染を考える意味で基碦的データを与え得ると思 考する。

\section{V. 結 論}

タンパク栄茇と，加龄による鉛中毒における硬組織中 $\mathrm{Ca}, \mathrm{P}, \mathrm{Pb}$ 含有量に取り込まれる鉛の影管について, young, adult ラットを用いて実験を行った。

1）全体的には, young 群が adult 群より鉛の取り 込みが大きかった。
2) young, adult 群ともに, $5 \%, 18 \% ， 30 \%$ たん 白掞取群の鉛の取り込みはほぼ $5 \%$ た白掞取群が他の 群に比べて大であり，切歯，大腿骨において，鉛の取り 込みがたん白栄荃を反映した。

3） young 群の場合, 大腿骨, adult 群では曰歯の鉛 取り込みが最大であった。

4） Ca およびPの含有整への鉛投与の影響は主に大 服骨において鉛群が高い傾向を示したが， $\mathrm{Ca} / \mathrm{P}$ 比につ いては adult 群で臼歯, 大腿骨にコントロール群との 間に差が珰められた。

稿を終るに当り，終始御指道を睗わった国立公衆衛生 院栄美生化学部長浦田郡平博士，並びに梶本雅俊室艮に 深时する。なお, 本論文の要旨は第27回口腔䢏生学会総 会，第28回口腔衛生学会總会において発表した。

\section{文献}

1) Chisolm, J. J.: Chronic lead intoxication in children, Develop Med Child Neurol, 7 : 529-536, 1965.

2) Underwood, E. J.: Trace elements in human and animal nutrition, 3rd edition, p. 436, Academic Press, 1975.

3）石波淑子，三島昌夫，風間発子，星合尚，丹 羽源男：人歯牙中の亜鉛㧍よびマグネシウム含 有盘, 日衛誌, $34: 697-705,1979$.

4) 堀口俊一, 堀内一弥 : 臨床化学（医化学実験法 講座), 中山書店, 東京, 1973, 393頁.

5) Fiske, C. H. and Subbarow, Y.: Determination of inorganic phosphate, J. Biol. Chem, $66: 375,1925$.

6）山田幸孝：食品中の微元素，日本食品衛生協 会, 東京, 1970, 18頁.

7) Keohoe, R. A.: Metabolism of lead under abnormal conditions, Arch Environ Health, $8: 225-243,1964$.

8）早川徳子, 高野由美, 跉木縁衣郎, 上野洋子： 鉛投与ラットの身体発育に抗よほす食畘たん白

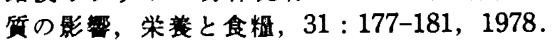

9) Strehlow, C. D.: The use of deciduous teeth as indicators of lead exposure, thesis, New York, 1971.

10) Strehlow, C. D.: The distribution of lead and zinc in the human skeleton, Amer. Hyg. Assoc. J., 30 : 372-378, 1962.

11) Altshuller, L. F., Halak, D. B. and Landing, B. K. : Deciduous teeth as an index of body burden lead, J. Pediatr, $60: 224-$ 229, 1962.

12) Shapiro, I. M., Needleman, H. L. and Tuncay, O. C.: The lead content of human deciduous and permanent teeth, Environ Res, 
$5: 467-470,1972$.

13) William, L. : Lead content of deciduous teeth of children in different environments, Arch Environ Health, 30 : 583-587, 1975.

14）倜内一确, 城口俊一, 宇都宮忠生 : 各種鉛化合 物の侵入，体内分布，排泄に関する研究 (6) 1 邓に対する各種鉛化合物の経口投与実倹の比較, 日衛誌, $24: 143,1969$.

15）西條良次, 向井哲郎, 中野碩夫, 倜口俊一：放 射性鉛を用いた生体内鉛代腤に関する実験的研 究, 日街誌, $29: 138,1974$.

16）丸田英夫, 西村正雄：鉛のラット硬組織への分 布に㧍よぼす加龄の影響，口衛誌，27:91-99, 1978.

17) James, H, Shaw and. Derrick, Griffiths :
Dental abnormalities in rats attributable to protein defficiency during reproduction, J. Nutr., 80 : 123-141, 1963.

18) Holloway, P. J., James, H. Shaw and E. A. Sweeney: Effects of various sucrose casein ratios in purified diets on the teeth and supporting structures of rats, Arch. Oral. Biol., $3:$ 185, 1961.

19) Menaker, L. and Navia, J. M. : Effect of undernutrition during the perinatal period on caries development in the rat. IV. The effect of differential tooth eruption and exposure to a cariogenic diet on subsequent dental caries incidence, J. Dent. Res., 52 : 692-697, 1973.

\section{Abstract: Effects of Protein Nutrition on $\mathrm{Pb}, \mathrm{Ca}$, and $\mathrm{P}$ Contents in Hard Tissues of}

Lead-administered Rats, Motoo NIWA*. The accumulation of lead, harmful to the living body, in hard tissues was investigated in relation to nutrition. An examination was also made of the quantitative changes in $\mathrm{Ca}$ and $\mathrm{P}$, measureing the constituent elements of hard tissues after lead administration. Lead-administered rats were fed on $5 \%, 18 \%$, and $30 \%$ protein diets for 4 weeks. Lead accumulation was largest in the group of rats fed on the $5 \%$ protein diet and was more remarkable in young rats than in adults. Quantitative changes in $\mathrm{Ca}$ and $\mathrm{P}$ were observed mainly in the femurs. 